\title{
Computer time-lapse microscopy of living cells with the TSITOMIR video complex: scientific, medical, and ecological possibilities
}

Sergey E. Dromashko*,

Oleg V. Kvitko,

Irina I. Koneva,

Yaroslav I. Sheiko,

Nina A. Balashenko,

Svetlana N. Shevtsova,

Anastasia S. Sapun

Genetic Processes Modelling Laboratory,

State Scientific Institution

"Institute of Genetics and Cytology",

National Academy of Sciences of Belarus

27 Akademicheskaya Street,

Minsk 22072, Republic of Belarus
Reliable testing of effects of various natural and synthetic substances on cells is critical in searching for effective inhibitory or stimulating agents. Such work is essential in the discovery of anticancer drugs and testing toxicity of newly synthesized compounds. We use the TSITOMIR ("World of Cells") computer video complex developed in cooperation with the Planar Corporation (Minsk). This complex is intended for time-lapse video microscopy of living cells (mouse and human fibroblasts, cells from human hair follicle and urine, cancer cultures). We elaborated a method for counting cells in low-density cell cultures to calculate the number of cells in the same growth substrate areas during cultivation, and to build cell genealogy trees. We also developed a non-invasive technology for receiving and analysing cells from human hair follicle and urine. It was shown that the cells obtained aged after a two-week cultivation, and therefore were not prone to immortalization, i.e., suitable for use in research for regenerative medicine. The method allows to obtain cell numbers in dynamics and makes it possible to get statistically valid quantitative data by using a minimal number of culture flasks. This approach can be exploited for testing antiproliferative and apoptosis-inducing effects, as well as the action of various substances and their combinations.

Keywords: time-lapse microscopy, TSITOMIR video complex, cell cultures, regenerative medicine, testing of natural and chemical substances

\section{INTRODUCTION}

With the development of computer and digital technologies, video microscopy has become widespread over the past decade. A microscope equipped with a computer video system has become a common device in many laboratories. The advantage of using a video system combined

\footnotetext{
* Corresponding author. Email: s.dromashko@igc.by
}

with a microscope is the possibility of convenient photographing (or video shooting) of microscopy objects followed by computer analysis of the received photo/video materials and preparation of visual and highly informative demonstration material.

When working with changing micro-objects, it is often required not only to photograph onetime, but also to record the dynamics of their changes on video. To record a video of slowly 
changing objects, time-lapse photography is used, i.e., shooting frames at specific intervals, for example, one frame per minute or per hour. Subsequently, a video is created from the captured frames.

In vivo video microscopy of cells allowed us to significantly refine and supplement the data on cell cultures obtained by visual observation. So, using long-term cell cultures, one can study the processes of cellular proliferation, differentiation, aging, and cancer transformation, to clarify their mechanisms, etc.

The article deals with some results of timelapse video microscopy obtained in the Genetic Processes' Modelling Laboratory from 2000 to 2017.

\section{MATERIALS AND METHODS}

Early results were obtained with the help of the TSITOLAIF ("Life of Cells") video system developed in the laboratory. Recent studies were performed on the TSITOMIR video complex.

The TSITOMIR video complex is a joint development of the Institute of Genetics and Cytology, the National Academy of Sciences of Belarus, and OptoElectronic Systems of Planar Corporation (Minsk) (Fig. 1). It consists of an inverted microscope MI-1 with a thermostatic camera (manufactured by the Planar Corporation), a thermostatically controlled system, and a video system. The microscope is equipped with a motorized table, which allows viewing the entire growth surface using a joystick and

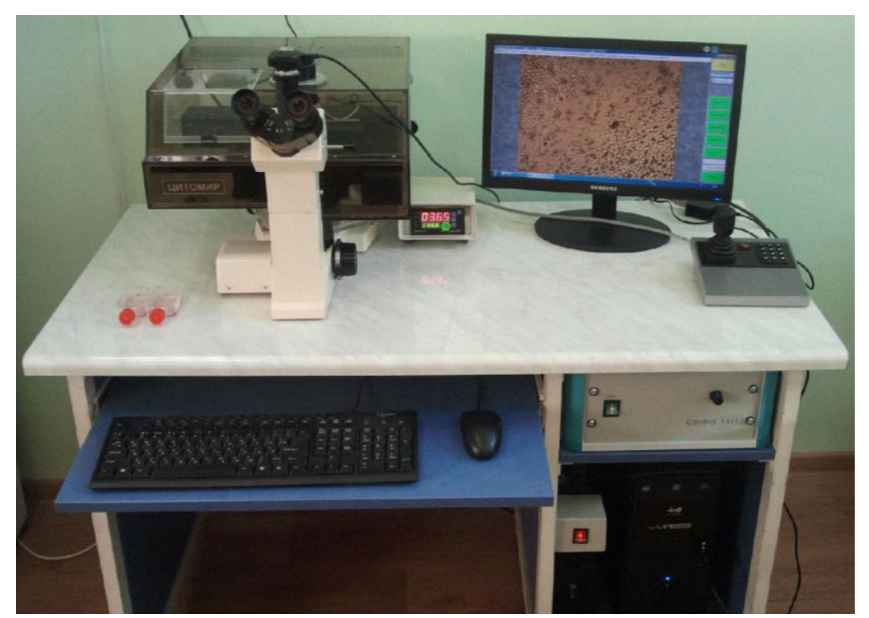

selecting the areas of interest. The coordinates of the selected areas are stored in the computer memory, which makes it possible to automatically photograph them at certain intervals. There are also modes for automatic scanning of standard 48 and 96 well plates without preliminary manual selection of areas. This allows quick photographing of all the wells of the tablet, or, in the case of long experiments, automatic photographing of all the wells of the tablet at regular intervals.

As the objects of the study, in vitro cultured human and mouse embryonic fibroblasts were used, an immortalized culture isolated from the Af-mouse mouse embryo, as well as standard cancers A549 and HeLa. For the preparation of cultures of normal (non-cancerous) cells, the skin-muscle tissue of 8-12-week-old human embryos and 12-14-day-old mouse embryos of the Af line were used. Isolation of embryonic cells and cultivation of the resulting or standard cultures was carried out according to the previously described procedures (Sheiko et al., 2002; Kvitko et al., 2005).

In particular, the tissue ground with scissors was disaggregated with a $0.25 \%$ trypsin solution at $37^{\circ} \mathrm{C}$ for 30 minutes. After removal of trypsin with a syringe, the precipitate was suspended in a growth medium comprising $90 \%$ of the Eagle's medium and $10 \%$ of foetal calf serum (ETS) with the addition of antibiotics. The slurry was passed through a capron filter (cell $0.3 \times 0.3 \mathrm{~mm}$ ). The concentration of single fibroblasts was counted in the Gorjaev's count chamber.
Fig. 1. TSITOMIR video complex to study living cell cultures 
Cells were plated in Carrel's vessels at a seed density in various experiments from 500 to $100-300,000$ per $1 \mathrm{~cm}^{2}$ of growth surface; in culture flasks, it was added with a syringe of $\mathrm{CO}_{2}$ (5\% volume), hermetically sealed with rubber plugs and cultured in the growth medium for 5-7 days. After formation of the monolayer, normal (non-cancerous) cells were removed with a mixture of trypsin solutions $(0.25 \%)$ and versene $(0.02 \%)$ at the ratio of $1: 1$, suspended in the growth medium and resected into Carrel's vessels for a number of passages until further experiments. In the case of immortalized or cancerous cultures, in some experiments the cells were transfected without trypsinization by centrifugation and transferring of cells from the spent nutrient medium.

The culture vessels were placed in a thermostatic chamber of the video complex (Fig. 1). With the help of visual browsing, the portions of the growth surface were selected for photographing. The frequency of shooting in different experiments varied from one frame per minute to one frame per day.

\section{RESULTS AND DISCUSSION}

\section{Differentiation of fibroblasts}

Video microscopy of living cell cultures made it possible to clarify the prevailing ideas about the behaviour of cultured fibroblasts based on the study of fixed preparations. Thus, in the works of Bayreuther and colleagues (Bayreuther et al., 1988; Bayreuther et al., 1992) the data on the inheritance of the morphotype in cell division are given, in which both daughter cells retain the maternal morphotype. In addition, we report asymmetric (differentiation) division in which the mother cell is divided into two children differing in morphotype - "saillike" and "spindle-shaped". Only the first type - sail-like fibroblasts - can be transferred to a tumour transformation (Fig. 2a).

However, analysis of the videotapes obtained from the video complex showed that the fibroblast culture cells moved quite actively and changed their shape. Attention was drawn to the considerable heterogeneity of cells in size and shape (Fig. 2b).

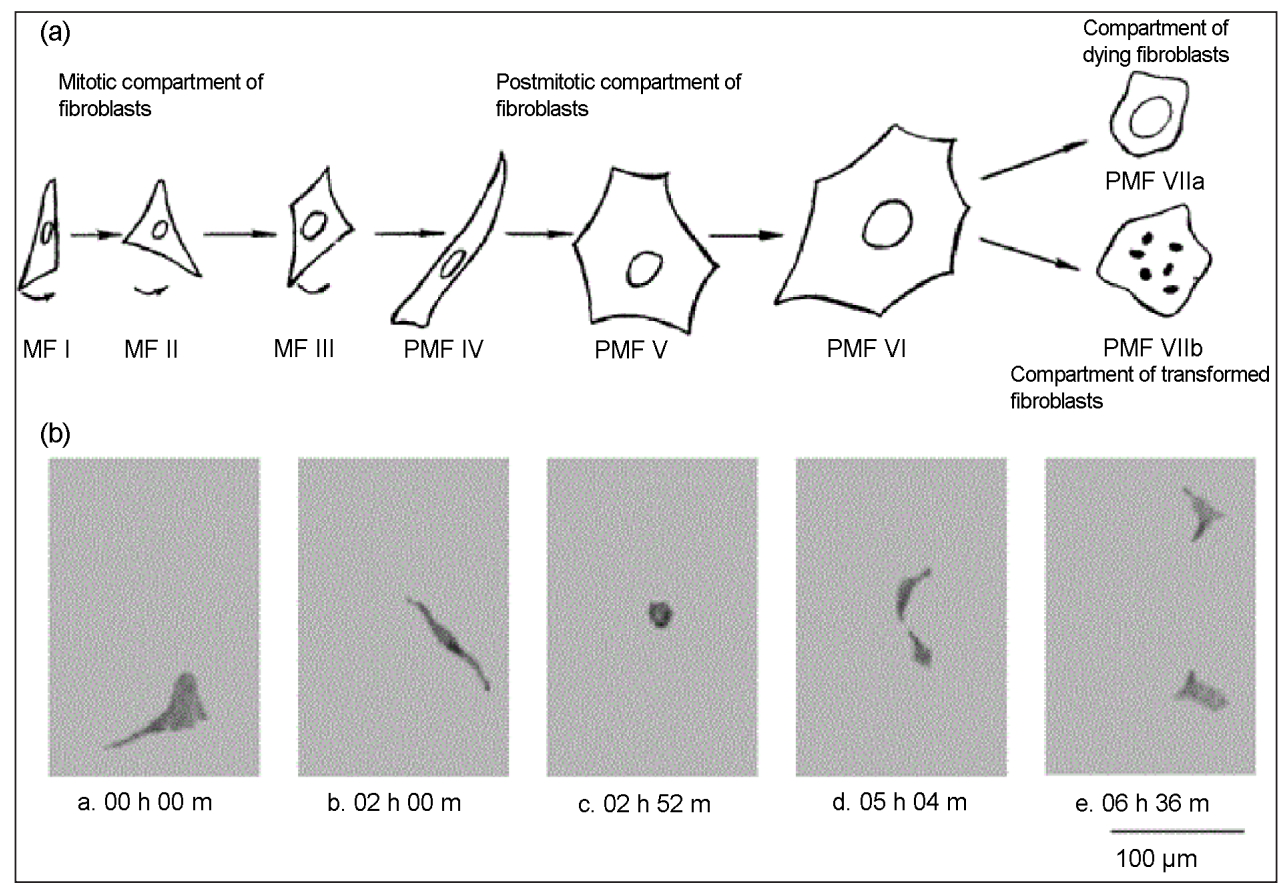

Fig. 2. Differentiation of fibroblasts (a) according to Bayreuther (1988) and (b) in our experiments

(a) MF - mitotic fibroblast, PMF - postmitotic fibroblast; (b) mitotic division of mouse fibroblast 
Our experiments showed that sail-like and spindle-shaped fibroblasts were different stages of one and the same cell development. In general, the form could change several times throughout the life of the cell (rounded, sail-like, spindleshaped, and various intermediate forms).

\section{Cellular genealogies: human and mouse}

About $80 \%$ of the time, mouse fibroblasts are in the sail-like stage, whereas human fibroblasts are in the spindle-shaped stage. This explains the sharp difference in the frequency of cancer transformation in a mouse and human. In terms of one cell generation, the transformation in mice occurs a million times more often than in humans. There are lines of mice in which all individuals fall ill with one or another type of cancer. Computer video microscopy allows building cellular genealogies (Fig. 3).

Quantitative analysis of cellular genealogies demonstrated a higher probability of mitotic division of large mouse cells compared to large human cells. If in human fibroblast cultures there were no cell divisions larger than $2300 \mu \mathrm{m}^{2}$, then in cultures of mouse fibroblasts large cells $\left(2300-5600 \mu \mathrm{m}^{2}\right)$ are divided as often as the rest of the cells.

\section{Experiments with immortalized mouse and rat cell cultures}

We selected immortalized lines of fibroblasts (Sapun et al., 2012). If the culture medium with mouse fibroblast secretions is added to the culture of ordinary human fibroblasts, it is possible to observe its accelerated reproduction (Table). On the one hand, this phenomenon can be used in medicine to accelerate the healing of wounds. On the other hand, however, there is a danger of stimulating cancerous transformation of cells.

Another interesting effect is triple and asymmetric mitoses in the immortalized culture of mouse fibroblasts. This phenomenon was observed in a number of generations and produced cells capable of further proliferation.

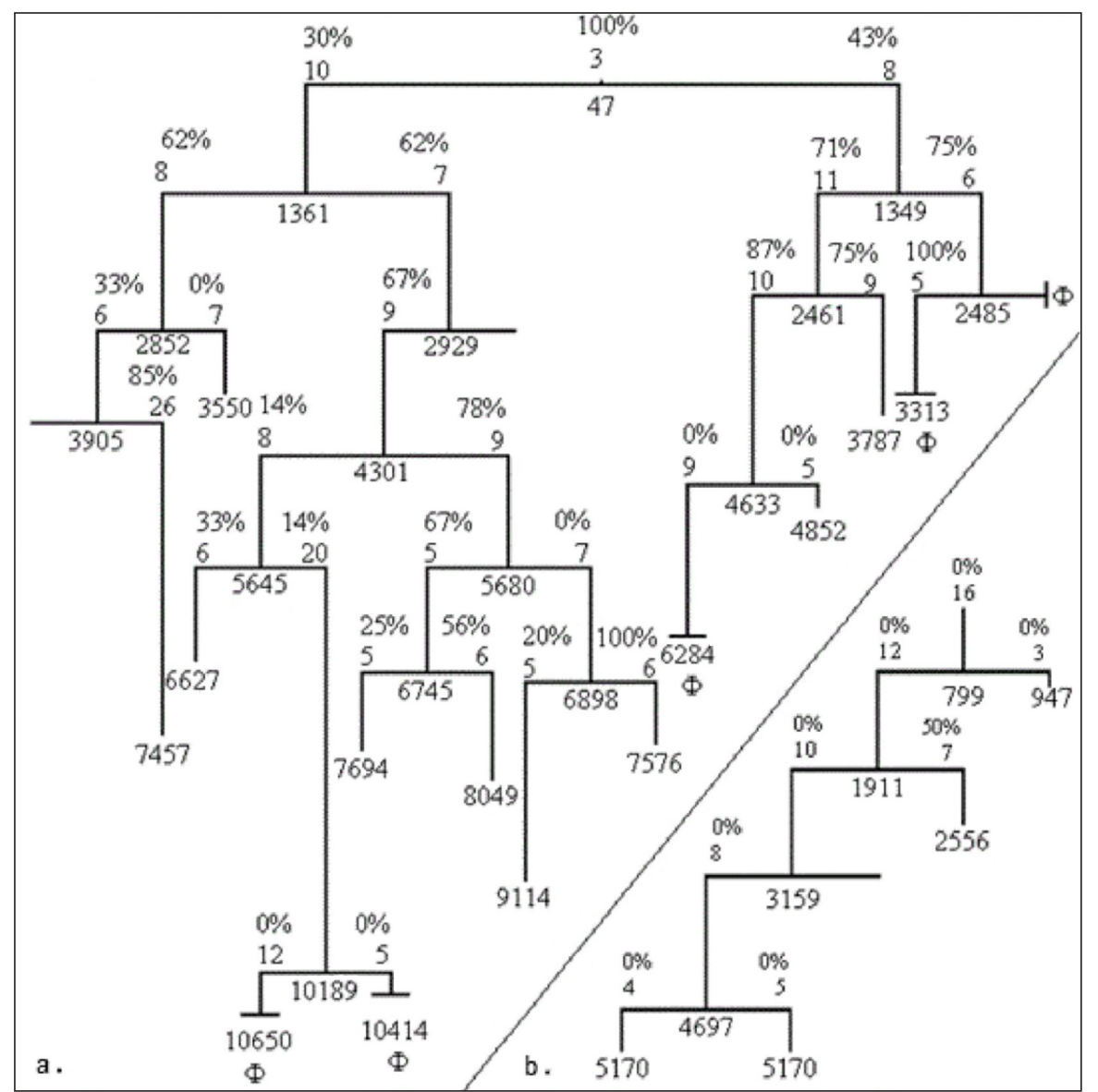

Fig. 3. An example of cellular genealogies: (a) human and (b) mouse; $\Phi$ (phi) death of a cell line 
Table. Stimulation of the human fibroblast proliferation with immortalized mouse cells

\begin{tabular}{c|c|c|c|c|c|c|c|c|c|c|c|c}
\hline Time (day) & $\mathbf{2}$ & $\mathbf{6}$ & $\mathbf{9}$ & $\mathbf{1 3}$ & $\mathbf{2 0}$ & $\mathbf{2 4}$ & $\mathbf{3 0}$ & $\mathbf{3 8}$ & $\mathbf{4 5}$ & $\mathbf{5 2}$ & $\mathbf{5 9}$ & $\mathbf{6 4}$ \\
\hline $\begin{array}{c}\text { Number of cells } \\
\text { (control) }\end{array}$ & 857 & 831 & 658 & 565 & 602 & 470 & 465 & 410 & 314 & 167 & 191 & 203 \\
\hline $\begin{array}{c}\text { Number of cells } \\
\text { (experiment) }\end{array}$ & 780 & 836 & 644 & $\mathbf{6 5 4}$ & $\mathbf{7 0 2}$ & $\mathbf{8 5 4}$ & $\mathbf{1 , 4 5 3}$ & $\mathbf{1 , 8 0 0}$ & $\mathbf{2 , 8 6 4}$ & $\mathbf{5 , 6 6 6}$ & $\mathbf{9 , 4 0 0}$ & $\mathbf{1 2 , 1 4 5}$ \\
\hline
\end{tabular}

* The moment of infusion of the culture liquid.

Using time-lapse video microscopy, we detected a process similar to cancer metastasizing. In the immortalized cell line isolated by us during the growth of the primary culture of fibroblasts obtained from 12-14-day-old embryos of Af mice, an anomalous multilayer growth of cells similar to those observed in the BALB/c mice line was sometimes observed (Rubin, 2001).

The analysis of video recordings showed that the transformed foci were formed not by local multiplication of single cells with a gradual increase in the area of abnormal growth, but as a result of aggregation of many cells of a growing monolayer culture. In Fig. 4a, three small, multi-layered foci can be seen, as well as individual cells and monolayer regions forming star-like structures. These foci are attracted to each other, along with the remaining monolayer of cells, and merge into one large cell aggregate. Large spherical aggregates of cells (up to $1 \mathrm{~mm}$ in diameter) were often detached from the growth surface in the culture medium.

It was found that there were large numbers of living cells, both in the aggregate attached to the substrate, and in the "floating" aggregate. The surface of these multicellular aggregates is a mass of actively moving cells. In addition, after collecting the aggregates that had become loose in the culture medium and placing them in a new culture vessel, the aggregates were attached to the substrate (Fig. 4b), after which the cells in them rapidly spread along the growth surface.

Recently we started its mathematical modelling in cooperation with A. V. Luikov Heat and Mass Transfer Institute. We expect to clarify the molecular mechanisms of cell aggrega- tion and subsequent separation. According to the model, once emerged under the impact of blows of Brownian particles, even a small aggregate starts to draw cells like a vacuum cleaner, increasing in size in accordance with the laws of hydrodynamics. As for modelling of cell output from the aggregate into a fresh nutrient medium, one can use heat equation, which is also suitable for describing mass transfer.

\section{Non-invasive (non-traumatic) isolation of human cells from hair follicles and urines}

In regenerative medicine, cellular technologies are already used to treat a number of diseases. Prospects for the development of this direction in medicine depend to a large extent on the development of non-traumatic and economic methods for obtaining autologous (own) cells, multiplied in vitro. From this point of view, a special interest is the possibility of obtaining autologous cells not surgically, but from follicles of plucked hair. In 1999, data were published that hair is constantly growing throughout life because hair follicles contain stem cells (Paus et al., 1999) and these stem cells are capable of forming not only hair follicles, sebaceous and sweat glands, but other types of cells.

A group of scientists from the University of California (Amoh et al., 2005) found that follicular stem cells can differentiate according to the neural type. This is evident not only in the appearance of cells, but also in the fact that they express $\beta 3$-tubulin. Experiments have shown that stem cells derived from mouse BVF express a marker of stem cells that have entered the neural-type neustin differentiation pathway. Also, cultured in vitro, these cells express CD34, which is also a marker of stem cells. 


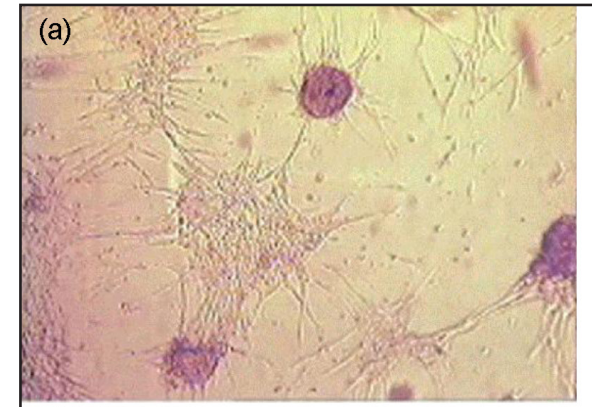

a $0 \mathrm{~h} 00 \mathrm{~m}$

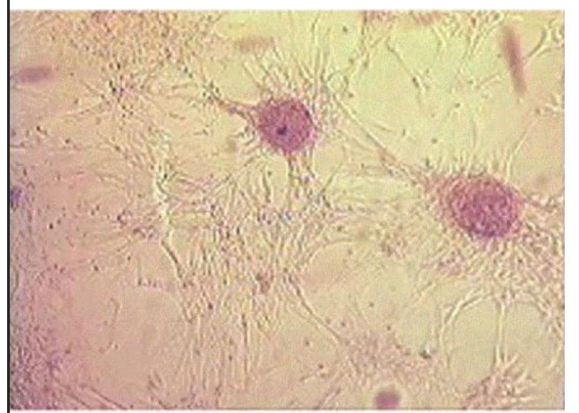

c $52 \mathrm{~h} 00 \mathrm{~m}$

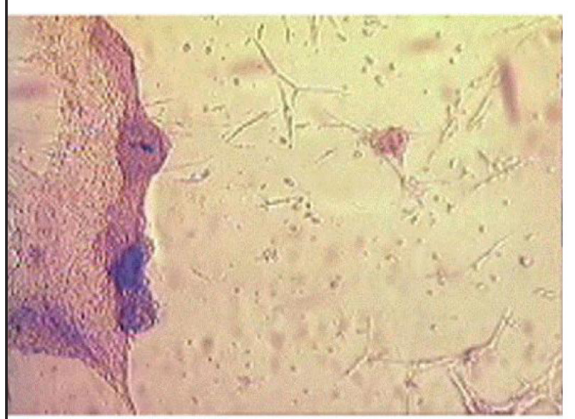

e 130 h 00 m
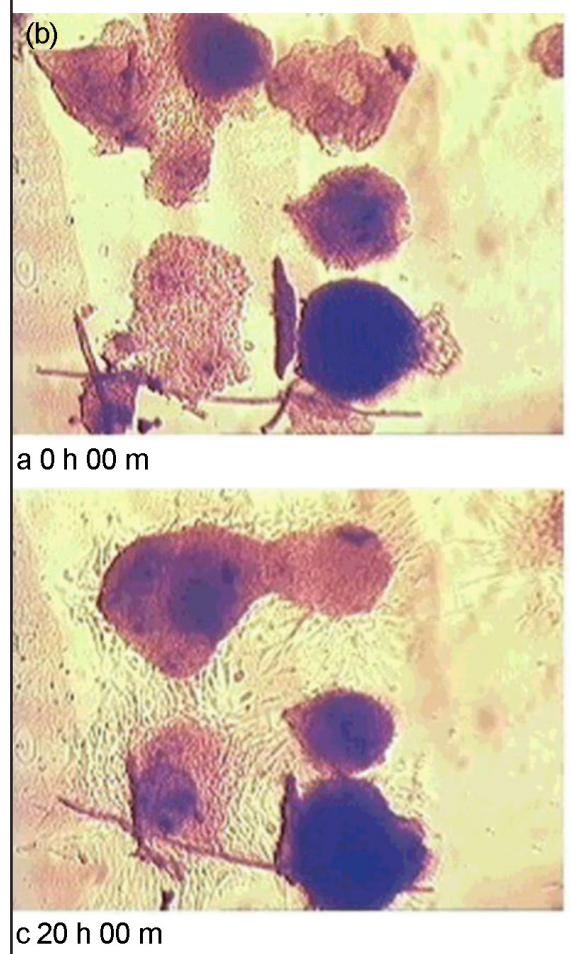

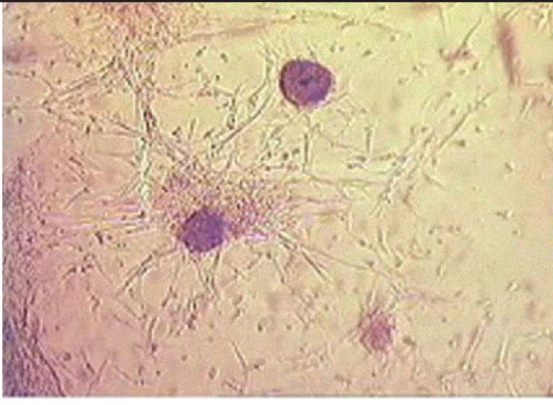

b $51 \mathrm{~h} 12 \mathrm{~m}$

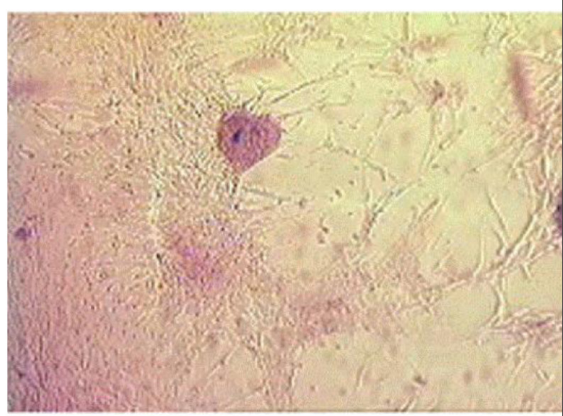

d $111 \mathrm{~h} 36 \mathrm{~m}$

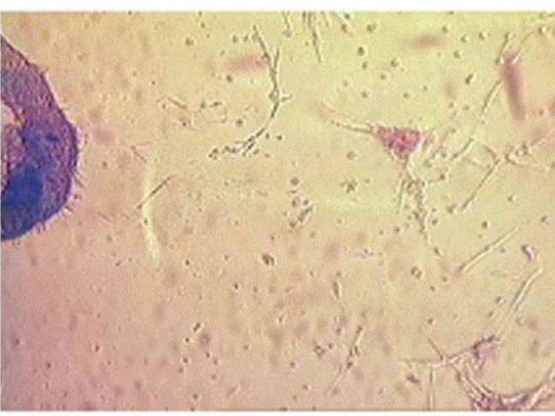

f 136 h 24 m
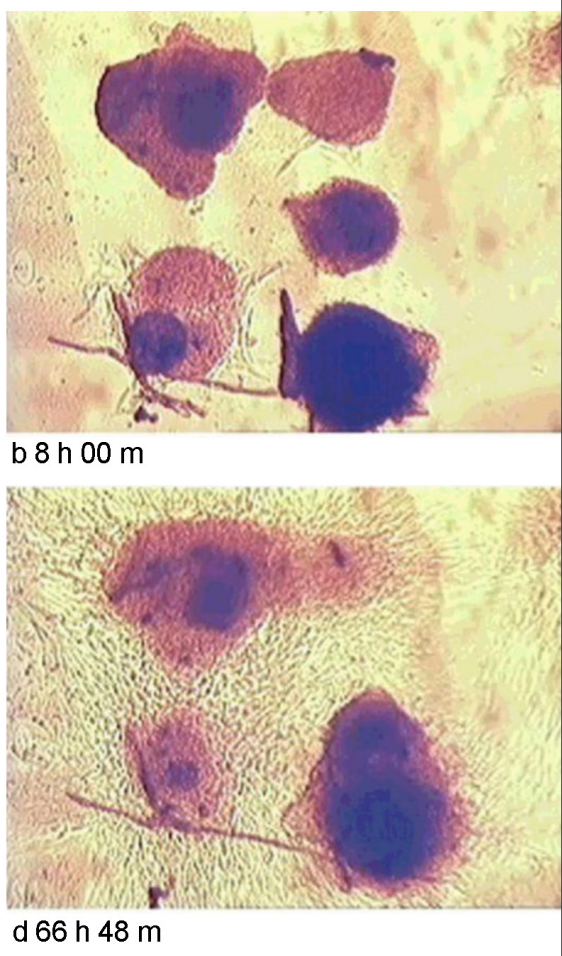

Fig. 4. Modelling of "metastasis": (a) multilayer cell focus in the immortalized culture; (b) release and propagation of cells from the focus 
We also obtained such an effect: if a cell line from the follicles of a human hair is pre-conditioned at a lower temperature $\left(30^{\circ} \mathrm{C}\right.$ versus standard $37^{\circ} \mathrm{C}$ ), after the initiation of induced differentiation cells begin to develop like neurons (Fig. 5).

We also obtained a live cell culture from the urine of healthy pregnant women. In addition to the fact that these cells shared and formed clones, they also aged. This indicates that we were able to isolate the cells that were not prone to a cancerous transformation. This is important in the case of their further use for the purposes of regenerative medicine.

We were the fourth in the world and the second in Europe to obtain human urine cells. Before us, such a result was achieved by two groups of researchers in China (one together with the Austrians), and a group in the US (also Chinese researchers) (Zhou et al., 2011).

Testing of chemical and biological substances Using the method of time-lapse video microscopy, it was shown that the inducer of the enzymes of the metabolic activation of betanaphthoflavone caused the death of mouse embryonic fibroblasts and showed a synergism with the inhibiting effect of mitomycin $\mathrm{C}$ promutagens and diazyquone.

It was also found that the herbicide 24-epibrassinolide modified the proliferation and apoptosis of embryonic fibroblasts.

We studied the effect of various concentrations of recombinant lactoferrin from the milk of transgenic goats on the proliferation and apoptosis of A549 lung cancer cells and the immortalized line of human embryonic fibroblasts (Sheiko et al., 2014). A clearly pronounced effect of the lactoferrin action was observed up to complete cell death after three-fold administration of lactoferrin at concentrations of 100 and $1000 \mu \mathrm{g} / \mathrm{ml}$ in the culture of immortalized human cells, the inhibitory effect increasing with the increased drug concentration (Fig. 6).

In cultures of lung cancer cells A549, lactoferrin was administered once or twice. Transgenic goats bearing a human lactoferrin gene are the result of a joint Russian-Belarusian project (the Institute of Gene Biology, the Russian Academy of Sciences, Moscow, and the Scientific and Practical Centre for Animal Breeding, the National Academy of Sciences of Belarus, Zhodino). Lactoferrin was introduced with the nutrient medium at the beginning of

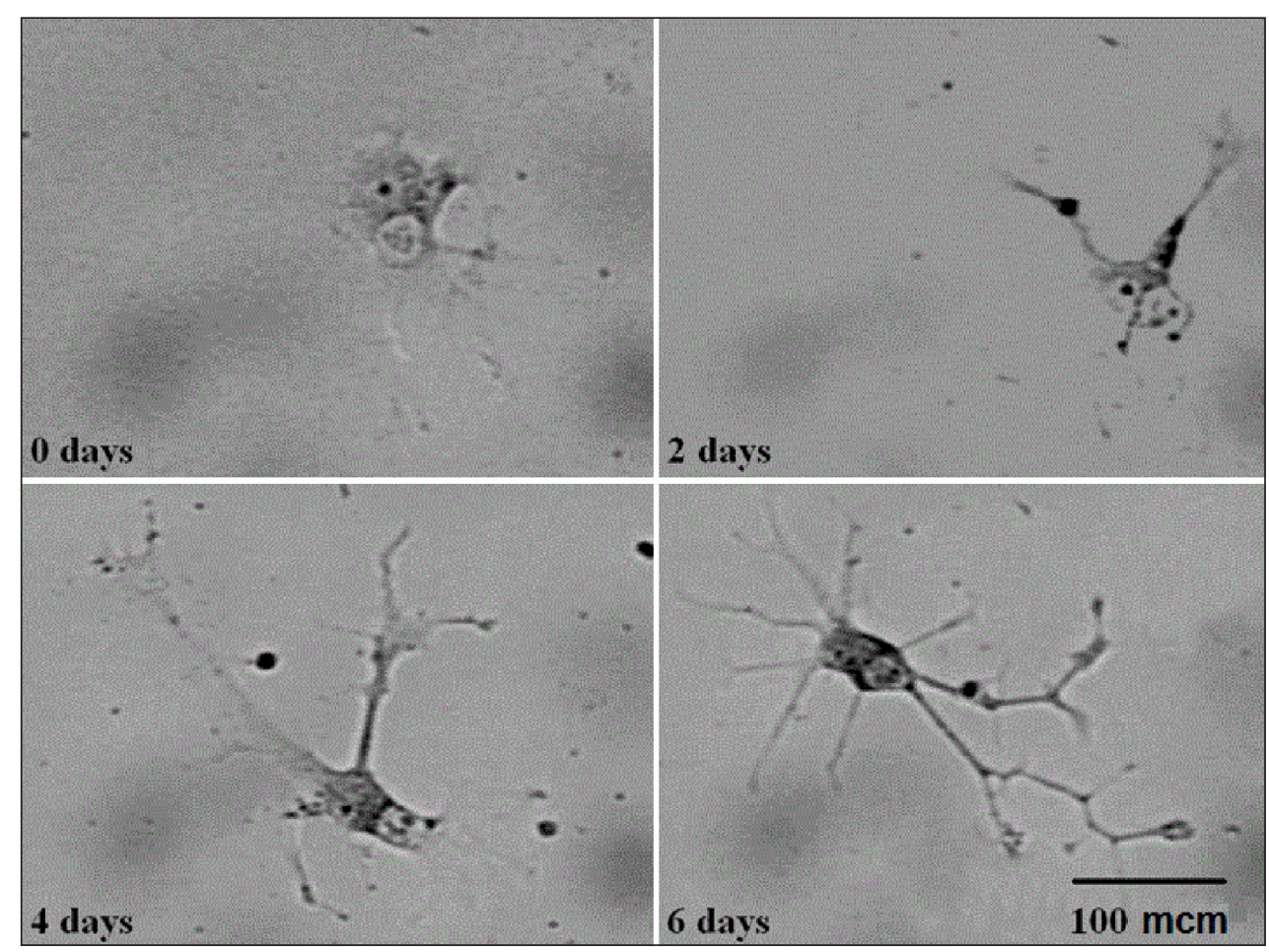

Fig. 5. Neuronlike differentiation of hair follicles 


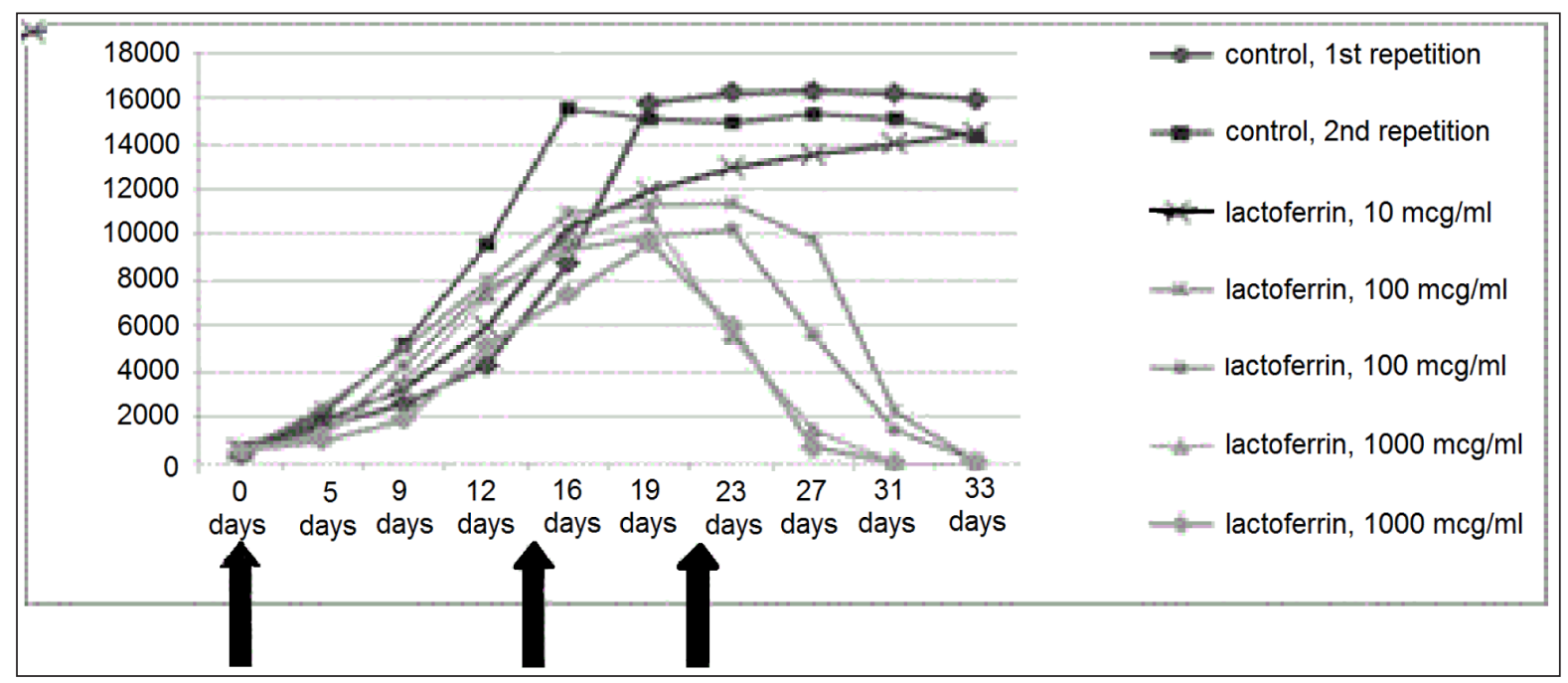

Fig. 6. The effect of human lactoferrin of transgenic goat milk on the cell number of an immortalized fibroblast line with three-stage treatment (arrows indicate days 1, 14, and 22)

cultivation and with a change in the culture medium after 8 days of cultivation. In some cells of the growth surface, a decrease in the number of cells was observed, but no reliable results on the inhibition of cancer cells' proliferation were obtained. The absence of a noticeable inhibitory effect of lactoferrin in these experiments appears to be due to a relatively short period of its effect on the cells.

The growth oppression in the culture of immortalized human fibroblasts showed an experiment on the effect of chicken erythrocyte DNA.

A drastic decrease in the cell number of immortalized human fibroblasts manifested at the three-stage treatment with Derinat - DNA water extract from sturgeon fish milk.

\section{CONCLUSIONS}

We used computer TSITOMIR video complex and time-lapse microscopy for living cell imaging in vitro. It allowed us to obtain new information about cellular aging and cell cancer transformation processes. Time-lapse microscopy is also a good technique for testing various xenobiotics and new drugs at the cell level.

We obtained immortalized cultures of human and mouse fibroblasts and used them as a model system for studying anti-cancer effects.
The method of computer video-microscopy using the TSITOMIR complex shows that recombinant human lactoferrin obtained from the milk of transgenic female goats-producers inhibits proliferation and induces cell death in the immortalized line of human embryonic fibroblasts.

Using time-lapse technique, we found a process similar to cancer metastasizing.

Received 21 May 2018

Accepted 7 June 2018

\section{References}

1. Amoh Y, Li L, Katsuoka K, Penman S, Hoffman RM. Multipotent nestin-positive, keratin-negative hair-follicle bulge stem cells can form neurons. Proc Natl Acad Sci USA. 2005 Apr 12; 102(15): 5530-4. Epub 2005 Mar 31. PubMed PMID: 15802470; PubMed Central PMCID: PMC556262.

2. Bayreuther K, Francz PI, Gogol J, Kontermann K. Terminal differentiation, aging, apoptosis, and spontaneous transformation in fibroblast stem cell systems in vivo and in vitro. Ann N Y Acad Sci. 1992 Nov 21; 663: 167-79. PubMed PMID: 1482050. 
3. Bayreuther K, Rodemann HP, Hommel R, Dittmann K, Albiez M, Francz PI. Human skin fibroblasts in vitro differentiate along a terminal cell lineage. Proc Natl Acad Sci USA. 1988 Jul; 85(14): 5112-6. PubMed PMID: 3393534; PubMed Central PMCID: PMC281698.

4. Kvitko OV, Koneva II, Sheiko YI, Anisovich MV. Hunting the mechanisms of self-renewal of immortal cell populations by means of real-time imaging of living cells. Cell Biol Int. 2005 Dec; 29(12): 1019-24. Epub 2005 Nov 23. PubMed PMID: 16309932.

5. Paus R, Botchkarev VA, Botchkareva NV, Mecklenburg L, Luger T, Slominski A. The skin POMC system (SPS). Leads and lessons from the hair follicle. Ann N Y Acad Sci. 1999 Oct 20; 885: 350-63. PubMed PMID: 10816666.

6. Rubin $\mathrm{H}$. The role of selection in progressive neoplastic transformation. Adv Cancer Res. 2001; 83: 159-207. PubMed PMID: 11665718.

7. Sapun AS, Kvitko OV, Koneva II, Sheiko YI, Balashenko NA, Dromashko SE. Spontaneous immortalization of rat fibroblasts during prolonged cultivation in vitro. Molekuliarnaia i prikladnaia genetika. 2012: 13: 118-25. Russian.

8. Sheiko YI, Kvitko OV, Koneva II, Tiurikov AP. Analysis of proliferation and differentiation of normal (aging) human and mouse fibroblasts by means of life-time videomicroscopy. Doklady NAN Belarusi. 2002; 46(1): 90-4. Russian.

9. Sheiko YI, Kvitko OV, Koneva II, Balashenko NA, Budievich AI, Dromashko SE. Study of effects of recombinant human lactoferrin on proliferation and apoptosis of cancer and immortalized cells. Molekuliarnaia i prikladnaia genetika. 2014: 18: 77-83. Russian.

10. Zhou T, Benda Ch, Duzinger S, Huang Y, Li X, Li Y, Guo X, Cao G, Chen Sh, Hao L, Chan Y-Ch, Ng K-M, Cy Ho JC, Wieser M, Wu J, Redl H, Tse H-F, Grillari J, GrillarVoglauer R, Pei D, Esteban MA. Generation of induced pluripotent stem cells from urine. J Am Soc Nephrol. 2011 Jul; 22(7): 1221-8. Epub 2011 Jun 2. PubMed PMID: 21636641; PubMed Central PMCID: PMC3137570.
Sergey E. Dromashko, Oleg V. Kvitko, Irina I. Koneva, Yaroslav I. Sheiko, Nina A. Balashenko, Svetlana N. Shevtsova, Anastasia S. Sapun

\section{GYVŲ LĄSTELIŲ KOMPIUTERINIS PERIODI- NIO FOTOGRAFAVIMO (ANG. TIME-LAPSE) MIKROSKOPAVIMAS TSITOMIR VAIZDO KOMPLEKSU: MOKSLINĖS, MEDICININĖS IR EKOLOGINĖS GALIMYBE்S}

\section{Santrauka}

Patikima ịvairių natūralių ir sintetinių medžiagų poveikio ląstelèms patikra yra labai svarbi ieškant veiksmingų slopinančių ar stimuliuojančių medžiagų. Toks darbas būtinas norint sukurti priešvěžinius vaistus ir patikrinti naujų sintetinių junginių toksiškumą. Tam tikslui naudojome kompiuterinio vaizdo kompleksą TSITOMIR („World of Cells“), sukurtą kartu su „Planar Corporation“ (Minskas). Šis kompleksas yra skirtas gyvų ląstelių (pelių ir žmonių fibroblastų, ląstelių iš žmonių plaukų folikulų ir šlapimo, vèžinių ląstelių kultūrų) periodinio fotografavimo (angl. time-lapse) mikroskopavimui. Mes patobulinome ląstelių skaičiavimo žemo tankio ląstelių kultūrose metodą, siekdami apskaičiuoti toje pačioje terpejje augančių ląstelių skaičių ir sukurti jų genealoginius medžius. Taip pat sukūrème neinvazinę technologiją, padedančią surinkti ir analizuoti žmogaus plauko folikulo ir šlapimo ląsteles. Paaiškèjo, jog ląstelès sensta po dviejų savaičių, joms nebūdingas tapsmas „nemirtingomis“, todèl šias ląsteles galima naudoti regeneratyvinèje medicinoje. Šis metodas leidžia skaičiuoti ląsteles dinaminejje aplinkoje ir gauti statistiškai patikimus kiekybinius duomenis naudojant nedaug kultūrų flakonų; taip pat jis gali būti naudojamas testuojant antiproliferacinius ir apoptozę skatinančius veiksnius, ịvairių cheminių junginių ir jų derinių veikimą.

Raktažodžiai: periodinio fotografavimo mikroskopavimas, sudètinis vaizdo filmavimas TSITOMIR, ląstelių kultūros, regeneratyvinè medicina, natūralių ir cheminių medžiagų testavimas 